\title{
A DESCRIPTIVE SURVEY OF A SEVENTH GRADE ART CLASS
}

\section{Donna Sharp}

This is a survey I made of my incoming seventh graders on their first day of classes with me. I wanted to know some things about them. I was curious about their feelings concerning school, and, more specifically, their views about art, based on their past experiences with it. I wondered how they thought they learned best, and what characteristics they $1 \mathrm{iked}$ and disliked in their teachers. I felt this information would help me understand what they considered important to learning.

There were 72 boys and 71 girls who participated in the survey. Their responses are summarized after each of the questions. The figures in the left column indicate the numbers who gave those specific replies.

Question \# 1: Right now, would you say you like art?

130 Yes

13 No

Question \# 2: Why, or why not?

(Positive responses)

31 I like to draw.

21 I like to make things./I like creating.

16 I like to work with clay.

14 We did fun stuff before.

13 It's fun.

9 You seem nice.

8 It's a new experience.

7 I had a nice teacher.

7 I just like it.

3 I like to paint.

3 I do okay in art.

2 It sounds interesting.

1 It's easy.

1 There are many opportunities in art. 


\section{Donna Sharp}

1 I like the results.

1 The class is smaller than before.

1 I like to carve.

1 Art is different than the other classes.

1 I get to use my skills to do different things.

(Negative responses)

11 I didn't like the teacher before.

6 It is boring.

2 I'm not an artist.

2 I draw terrible.

1 I don't like to draw.

1 I don't like art. I never have.

1 I didn't have enough time to get my work done.

1 I don't like getting clay on me.

Question \# 3: What kind of thing in art do you like to do best?

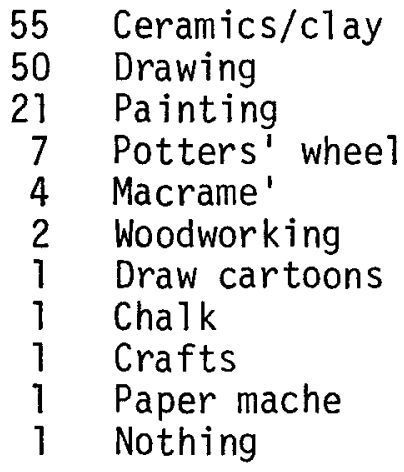

Question \# 4: What is something you'd like to learn in art?

34 Potters' wheel

23 Learn to draw better

16 Work with clay better

11 Leather

10 Stained glass

Macrame

How to paint better

Sculpture

How to make candles

Silkscreen

How to mold things

Crochet

Carving

How to draw cartoons

Sewing

Airbrush techniques

1 Commercial art 


\section{Donna Sharp}

1 Woodburning

How to build a house

Toots

Woodcrafting

Everything

About past artists

Pipecleaner people

Welding

Wood toys

Knitting

Weaving

Glassblowing

How to make better stuff

Question \# 5: What do you like about school?

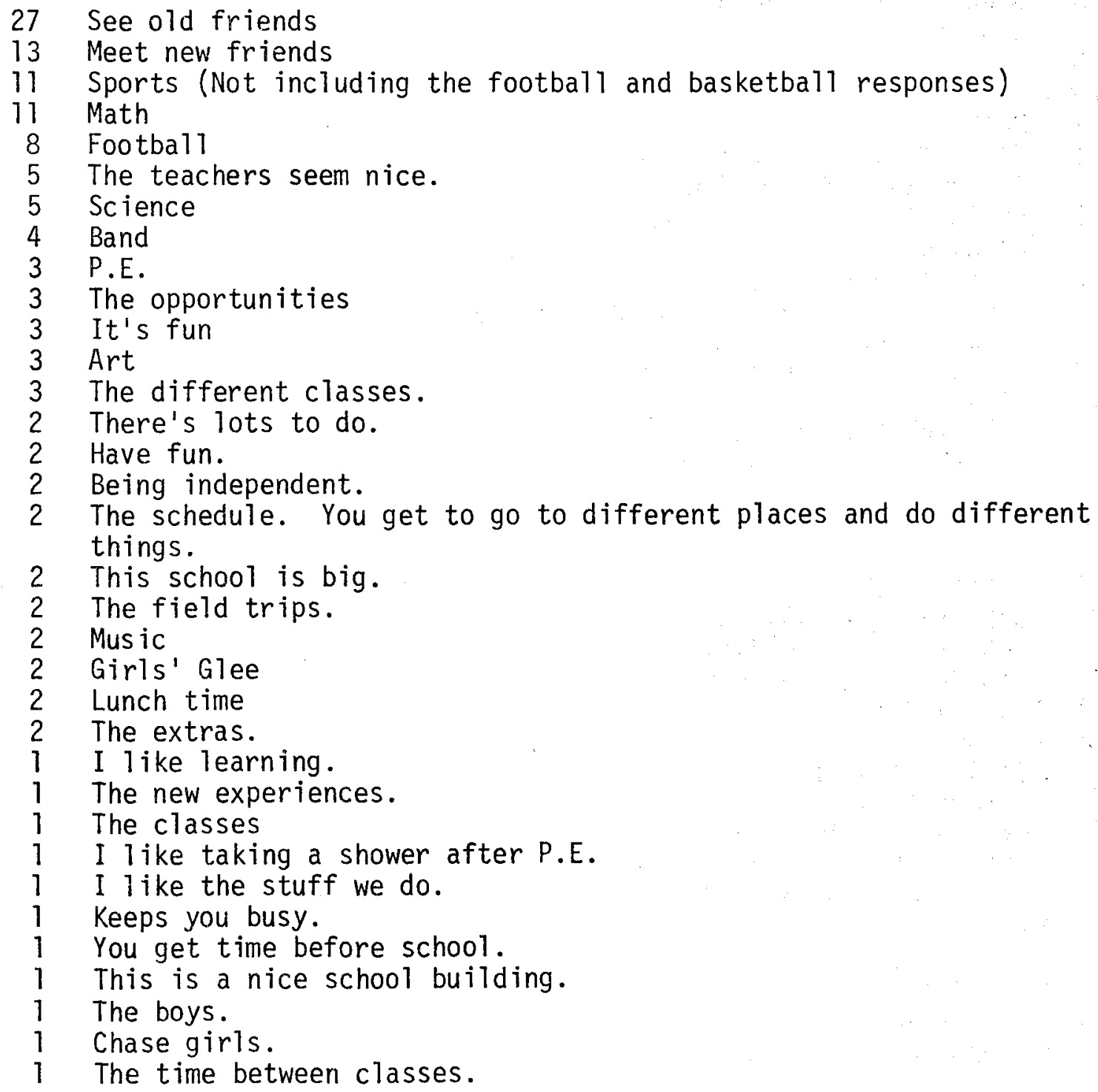




\section{Donna Sharp}

Learn a lot.

I just like school.

We're not with the little kids.

Get to switch classes and see our friends.

Study hall

I like all the people and all the classes.

The work.

The new stuff.

It's a bigger adventure than elementary.

Question \# 6: What do you dislike about school?

13 Homework

12 The heat/Having to go to school when it's hot!

9 The teachers are mean.

8 Showers after P.E./Having to take showers. Too short of time to take showers after P.E.

6 The work

5 Social Studies

4 Math

$4 \quad$ I'm not with my friends.

4 The crowded ha11s./The school is crowded.

3 Having to rush to classes.

3 Nothing

3 Getting lost.

3 The teachers aren't reasonable and yell.

3 It's boring.

2 Short time between classes.

2 Science

2 Teachers talk too much.

2 Too short of lunch time.

2 Too long of class time.

2 The strange/weird people.

2 No recess.

1 I eat lunch.

1 School wastes your money.

1 School wastes your time.

1 Waste your money on gym clothes.

1 Mus ic

1 The open area

1 Boring assemblies

1 I have to go to my locker or have to carry so many books around.

1 The busyness

1 The teachers don't tell you enough.

1 When people stare at you because you've got new clothes on.

1 Walking to class.

1. This is so big.

1 Assigned seats

1 Everything

1 People who don't like me.

1 Getting up early. 


\section{Donna Sharp}

Question \# 7: How do you think you learn best?

45 Seeing/Demonstrations/Examples/Show me

27 Explain it to me

15 Listening well/Paying attention.

10 Reading/If I read it I can remember it.

5 If I can take my time./If I can work at my won pace.

3 By actually doing something myself.

3 By taking notes.

2 Practicing.

2 Studying.

2 If there is a quiz or a test.

1 Working alone.

1 In the 1 ibrary by myself.

1 Asking questions.

1 When teachers yell at me.

1 When I have a strict teacher.

1 When teachers help you at your work.

1 By going to school.

1 Getting exact directions.

1 When it is quiet.

1 When I can see other people's work.

Question \# 8: What are some things that you like teachers to do or that you like that teachers do?

Are helpful.

Are nice.

13 Explain things clearly so we can understand.

12

Have a sense of humor.

Understand us.

Know you./Pay special attention to you.

Compl iment you.

Be patient and calm

Give you good grades.

Tell you what things you did wrong.

Write comments on your papers.

Smile a lot.

Interested in you.

Let you talk in class.

Give you enough time in class to get your work done.

Don't treat us like babies.

Show us how to do things.

Get along with you.

Let you sit anywhere.

Give extra credit.

Take us on field trips.

Let you work at your own speed.

Let us out of school.

Let us kids chew gum.

1 Give easy work. 


\section{Donna Sharp}

1 Ask questions.

1 Are fair.

1 Don't talk behind your back.

1 Are so organized

1 Let us go to the Media Center.

1 Let me print because I can't write.

1 Give worksheets and stuff to fill and color.

1 When they leave the room.

1 When they don't have favorites or pets.

1 When they keep on the subject.

1 When they make me do my work.

$1 \quad$ Nothing

Question \# 9: What are some things you dislike about teachers or that teachers do?

27

Ta]k too much

21 Yell

8 Get mad

5 Don't explain things so we can understand.

5 Give homework.

4 Don't listen to you.

4 Blame you for something you didn't do.

3 Are mean

3 Give bad grades

3 Treat you like a baby.

3 Ignore you

3 Don't give enough time to get our work done.

2 Don't tell you how to correct things.

2 Rush us

2 Mark over our paper

1 Pick favorties.

1 Tell you to D0 IT!

1 Don't let you chew gum

1 Give hard assignments

1 Have assigned seats

1 Force you to do things.

1 Have scorecards

1 Write sloppy so we can't read it.

1 Look over my shoulder.

1 Stay in the room.

1 Say our grades out loud.

1 Not sticking to their word.

1 Give tests

1 Go through things too slowly.

1 Don't believe our excuses.

1 Don't stay on the subject.

1 Talk too quiet

1 Too strict

1 If you raise your hand you don't get picked.

1 Give you an $F$, but it's suppose to be an $A$. 


\section{Donna Sharp}

1 You do okay, but you get a bad grade.

1 Give bad grades

Question \# 10: What is your favorite subject?

$\begin{aligned} 40 & \text { Math } \\ 36 & \text { Science } \\ 21 & \text { Art } \\ 20 & \text { P.E. } \\ 16 & \text { Reading } \\ 9 & \text { Music } \\ 5 & \text { Social Studies } \\ 4 & \text { Spelling }\end{aligned}$

3 Language Arts

3 Shop

3 Homeroom

1 Glee

1 Basketball

1 Study Hal1

1 Lunchtime

Question \# 11: In what subject do you feel you do best?

$\begin{aligned} 39 & \text { Math } \\ 25 & \text { Science } \\ 19 & \text { Reading } \\ 17 & \text { Art } \\ 12 & \text { P.E. } \\ 12 & \text { Speiling } \\ 7 & \text { Music } \\ 6 & \text { Language Arts }\end{aligned}$

Question \# 12: What is your least favorite subject?

$\begin{aligned} 26 & \text { Language Arts } \\ 23 & \text { Social Studies } \\ 21 & \text { Math } \\ 14 & \text { Reading } \\ 9 & \text { Music } \\ 8 & \text { Science } \\ 7 & \text { Spelling } \\ 2 & \text { Art } \\ 2 & \text { P.E. } \\ 1 & \text { Study Hall }\end{aligned}$

The students' reasons for liking art centered on what was made, or the nature of the art activity. Some of the replies, such as, "It's easy," and, "You seem nice," reflect little of what art teachers consider important. The negative responses are even more revealing to me. Why does a kid get turned off to art? Because of the teacher. Because he or she thinks it is boring. 


\section{Donna Sharp}

Many of the students' reactions to school focus on the adjustments from smaller elementary schools to the larger junior high school. For example, some liked the schedule which allowed them "to go different places and do different things," while others disliked the "short time between classes." I really thought about the number who said they disliked homework. This is rather new to them, but is much more familiar than lockers or showers. I feel that students at this stage in life have other ideas about how to use their time at home, such as playing. They often want to forget about school when they are at home.

Their answers to the questions about the kinds of things that teachers do which they like or dislike were not as helpful to me as I had hoped they would be. Some phrases are ambiguous. "Are helpful" caused me to wonder about what is seen as being "helpful." Does it mean that you talk to each student every day? Does it mean that you are quick to give assistance so that students do not have to wait for a response to questions or problems? A similar difficulty is presented by the word "nice." How do students interpret this quality? The "give good grades" response is perplexing because teachers view grades as being attained by the students.

It required considerable time to record and tabulate the information from this survey because almost all of the questions were open-ended. However, I felt they were necessary to collect the information I wanted to know. 